\title{
Transaction Costs and Corporate Tax Stickiness: Based on Big Data Analysis
}

\author{
Xiaojuan $\mathrm{Wu}^{* 1, \mathrm{a}}$,Hongwei Cheng ${ }^{2, \mathrm{~b}}$ \\ ${ }^{1}$ Business School Sichuan University Chengdu, China \\ ${ }^{2}$ Business School Sichuan University Chengdu, China
}

\begin{abstract}
According to deduction principle in China's tax law, the excess transaction costs of enterprises are limited. Therefore, the higher the rate of enterprise transaction costs, the higher the transaction costs cannot be deducted before tax, resulting in the taxable income tax greater than the accounting profit. From the dynamic perspective, it is difficult to reduce the income tax burden when the accounting profit of the enterprise decreases, which will enhance the stickiness of the enterprise tax burden. On the basis of this theoretical analysis, this paper empirically tests the relationship between transaction costs and corporate tax stickiness with the big data samples of Chinese listed companies from 2009 to 2018 . The empirical results show that with the increase of transaction cost rate, the stickiness of corporate tax burden will be strengthened.
\end{abstract}

\section{Introduction}

Recent years, scholars have found that there is a non-linear and asymmetric relationship between the tax burden and the change of corporate profits in China, and this phenomena of corporate tax stickiness has become a hot topic in the theoretical and practical communities (Wang et al.,2018 [1]; Liu and Xue, 2019 [2]). However, if there is no book-tax difference, there must be a linear relationship between tax burden and accounting profit. Therefore, to study the stickiness of the enterprise tax burden, we have to understand why book-tax differences arise. However, the existing research on corporate tax stickiness is mainly conducted from an external perspective. It is believed that Chinese government's rigid tax plan is the main cause of tax stickiness in China (Bai and Tang, 2018 [3]). However, enterprises are the creators of taxes and profits. Can the national macro tax plan fully explain the corporate tax stickiness in micro field? With this question, we try to find out the institutional roots and micro facts behind the stickiness of corporate tax burden, starting from the generating logic of book-tax differences.

Compared with Chinese accounting standards and tax law, it can be found that accountant tends to recognize more expenses out of the principle of conservatism (Li and $\mathrm{Lu}, 2003$ [4]), but the tax law respects the principle of reasonableness and the principle of cash basis, and limits the deduction of transaction costs incurred by enterprises, especially those unreasonable expenses exceeding the deduction standard (L.Liu,2006 [5]). The nondeductible transaction costs will lead to the enterprise's taxable income greater than the accounting profit, resulting in book-tax differences and increasing the tax burden of enterprises. This phenomenon is more obvious when the

\footnotetext{
$\mathrm{a}^{*}$ Corresponding author: wuxj1990@163.com

bchenghw@scu.edu.cn
}

transaction costs increase significantly. From the dynamic perspective, when the transaction costs incurred by enterprises only be partially deducted by the tax law, it will be difficult to reduce the income tax burden as the accounting profit of the enterprise decreases. That is to say, when the accounting profit of the enterprise decreases, the decrease range of the tax burden of the enterprise is smaller than that of the increase of the tax burden when the accounting profit of the enterprise rises in the same proportion, which means the change of the tax burden is sticky (Wang et al.,2018 [1]; $\mathrm{Hu}$ and Wu,2020 [6]). However, whether the transaction costs will increase the stickiness of corporate tax burden is still lack of empirical evidence.

Through big data analysis, we can identify the internal relationship between phenomena. Based on the big data of Chinese listed companies from 2009 to 2018, we empirically test the relationship between transaction costs and corporate tax stickiness. The empirical results show that with the increase of transaction cost rate, the stickiness of corporate tax burden will be strengthened. The results of this study can help to explain why in the economic downturn, the transaction costs of enterprises rise, and more enterprises feel that the tax burden is heavier. At the same time, we believe that the stickiness of corporate tax burden is one of the economic consequences of the restrictive deduction of expenses in China's income tax law.

\section{Hypothesis}

Transaction cost is an important deduction item of enterprise income tax. The principle of rationality of pre tax deduction in China's tax law reflects the restriction and regulation of the government to the enterprise behavior. 
The principle of rationality requires that the unnecessary transaction expenses beyond the normal production and operation process cannot be deducted before tax. For example, according to the deduction principle, business entertainment expenses exceeding $0.5 \%$ of the enterprise's sales revenue cannot be deducted before tax. The nondeductible expenses lead to the enterprise's taxable income more than the enterprise's accounting profit, increase the enterprise's tax burden, force the enterprise to reduce excess business entertainment expenses and improve management efficiency. In the period of economic downturn, the transaction costs of enterprises increase, and the expenses that cannot be deducted increase. At this time, when the profits of enterprises decrease, the tax burden is difficult to fall, which means that the sensitivity of enterprise tax burden to profit change is low and the degree of tax stickiness is high. Therefore, it can be inferred that the higher the transaction cost rate is, the lower the sensitivity between the change of corporate income tax burden and the change of profit, and the higher the stickiness of corporate tax is. Therefore, we put forward the following hypotheses.

Hypothesis: the higher the transaction cost rate is, the lower the sensitivity between the change of enterprise tax burden and the change of profit, and the higher the degree of enterprise tax stickiness.

\section{Data, key variable definitions and research methods}

\subsection{Data}

We select China's A-share listed companies from 2009 to 2018 as the initial sample. And then deals with the initial sample according to the following standards: (1) excluding the companies with negative tax burden; (2) excluding companies with negative accounting profit during the sample period; (3) excluding companies in the financial industry; (4) eliminate other samples with missing values. Furthermore, we winsorize all continuous variables at the $1^{\text {st }}$ and $99^{\text {th }}$ percentiles to avoid the influence of outliers. Finally, 8610 annual observations are obtained. The financial data are all from CSMAR database. The empirical test tool is Stata. 15.0.

\subsection{Key variable definitions}

\subsubsection{Dependent Variable}

Referring to the existing research, the income tax burden (IT) of enterprises is the current income tax expense minus the current deferred income tax expense (Liu and Ye, 2014 [7]). The dependent variables $\operatorname{Ln}\left(I T_{i, t}\right)$ and $\operatorname{Ln}\left(I T_{i, t} / I T_{i, t-1}\right)$ are the natural logarithm of the current income tax burden and the natural logarithm of the ratio of the current corporate income tax to the previous corporate income tax burden, respectively.

\subsubsection{Independent Variable}

$\operatorname{Ln}\left(\right.$ Inco $\left._{i, t}\right)$ is the natural logarithm of the total accounting profit of the current period, and $\operatorname{Ln}\left(\operatorname{Inco}_{i, t} /\right.$ Inco $\left._{i, t-1}\right)$ is the natural logarithm of the ratio between the total profit of the current year and that of the previous year. $D$ is the dummy variable of total profit decrease. When the total profit decreases to the previous year, take 1 , otherwise take 0 . Fee is the ratio of transaction costs (including administrative expenses, sales expenses and financial expenses) in the total revenue of an enterprise.

\subsubsection{Control Variable}

According to the practice of other scholars, we controls the variables that may affect the tax burden and its changes. It includes enterprise characteristics such as property right (Private), enterprise size (Size), financial leverage (Lev), profitability (Roa), enterprise capital intensity (PPE), enterprise inventory density (INVE), cash holding status (Cash), earnings management degree (DA) and enterprise age (Age), And the external environmental factors such as the intensity of tax collection and management $(E N F)$, the financial pressure of regional government (SRZC), macroeconomic prosperity $(G D P)$. At the same time, due to the differences of tax policies in different regions of China, the regional effect (Dist) is also controlled (Y.C. Feng, 2012 [8]). We also controls the industry impact (Ind) and annual effect (Year) in our models.

\subsection{Research Methods}

Firstly, referring to the sensitivity model of Luo Hong et al. (2015), we design the following model(1) to test whether the increase of transaction costs will reduce the sensitivity of enterprise tax burden to profit changes(Luo Hong et al,2015 [9]).

$$
\begin{aligned}
& \operatorname{LnIT}_{i, t}=\beta_{0}+\beta_{1} \operatorname{Ln}\left(\text { Inco }_{i, t}\right)+\beta_{2} \times \operatorname{Ln}\left(\text { Inco }_{i, t}\right) \times \mathrm{Fee}_{i, t}+\beta_{3} \mathrm{Fee}_{i, t}
\end{aligned}
$$

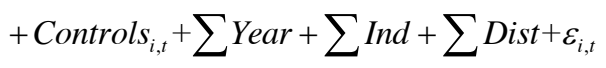

According to the definition of the model, if the coefficient of cross variable $\operatorname{Ln}\left(\operatorname{Inco}_{i, t}\right) \times F e e_{i, t}$ is significantly negative, it can be verified that the increase of transaction costs will weaken the sensitivity of enterprise income tax burden to the change of accounting profit..

Furthermore, referring and integrating the methods of Wang et al., (2018) and Banker (2013), we use model (2) to test whether there is stickiness in the change of corporate income tax burden(Wang et al.,2018 [1]), and then establish the model (3) to test whether the transaction costs of enterprises will enhance the stickiness of corporate income tax burden(R.D. Banker, 2013 [10]).

$$
\begin{aligned}
\operatorname{Ln}\left(\frac{I T_{i, t}}{I T_{i, t-1}}\right)= & \beta_{0}+\beta_{1} \operatorname{Ln}\left(\frac{\text { Inco }_{i, t}}{\text { Inco }_{i, t-1}}\right)+\beta_{2} \times D_{i, t} \times \operatorname{Ln}\left(\frac{\text { Inco }_{i, t}}{\text { Inco }_{i, t-1}}\right) \\
& + \text { Controls }_{i, t}+\sum \text { Year }+\sum \text { Ind }+\sum{\text { Dist }+\varepsilon_{i, t}}_{(2)}
\end{aligned}
$$




$$
\begin{aligned}
\operatorname{Ln}\left(\frac{I T_{i, t}}{I T_{i, t-1}}\right) & =\beta_{0}+\beta_{1} \operatorname{Ln}\left(\frac{\text { Inco }_{i, t}}{\operatorname{Inco}_{i, t-1}}\right)+\left(\lambda_{0}+\lambda_{1} \text { Fee }_{i, t}+\text { Controls }_{i, t}\right. \\
& \left.+v_{i, t}\right) \times D_{i, t} \times \operatorname{Ln}\left(\frac{\text { Inco }_{i, t}}{\text { Inco }_{i, t-1}}\right)+\sum \text { Year } \\
& +\sum \text { Ind }+\sum \text { Dist }+\varepsilon_{i, t}
\end{aligned}
$$

According to model (2), if the coefficient of variable $D \times \operatorname{Ln}\left(\right.$ Inco $\left._{i, t} / \operatorname{Inco}_{i, t-1}\right)$ is significantly negative, it indicates that there is stickiness in the change of tax burden. According to model (3), if the coefficient of variable $D \times \operatorname{Ln}\left(\right.$ Inco $_{i, t} /$ Inco $\left._{i, t-1}\right) \times F e e$ is significantly negative, it shows that the increase of transaction costs has the effect of increasing the stickiness of corporate income tax.

\section{Results}

Table 1 presents the descriptive statistical results of the main variables of the sample. It can be seen that the mean values of variables $\operatorname{Ln}\left(I T_{i, t} / I T_{i, t-1}\right)$ and $\operatorname{Ln}\left(\operatorname{Inco}_{i, t} / \operatorname{Inco}_{i, t-1}\right)$ are 0.124 and 0.087 respectively, which are greater than 0 , indicating that the overall trend of corporate profits and income tax burden in the sample period is on the rise. The average value of variable $D$ is 0.356 , which indicates that $35.6 \%$ of the samples have a decline in total profit. The average ratio of sales and management expenses is 0.187 , which indicates that the average proportion of transaction expenses in operating revenue is $18.7 \%$. Finally, the average value of the ratio of fiscal revenue to fiscal expenditure $(S R Z C)$ is 0.679 , which indicates that there is a widespread problem of fiscal deficit in various regions of China. The average value of tax collection and management intensity $(E N F)$ is 1.023 , which indicates that the actual tax revenue of various regions in China has reached or even exceeded the expected tax revenue, which is consistent with the tax collection and management system born out of government's tax plan (Y. X. Bai, 2018 [3]). The average of enterprise earnings management $(D A)$ is 0.059 , which indicates that China's enterprises carry out positive earnings management, and the earnings reported by enterprises are relatively radical. The descriptive statistical results of other indicators are basically consistent with the existing literature, indicating that the statistical results of the article are relatively accurate.

Table1. Descriptive statistics

\begin{tabular}{|l|c|l|c|l|l|}
\hline \multicolumn{1}{|c|}{ Variables } & Obs & Mean & S.D. & \multicolumn{1}{c|}{ Min. } & Max. \\
\left.\hline${\text { Ln }\left(I T_{i, t} / I T_{i,-1}\right)}\right)$ & 8610 & 0.124 & 0.737 & -2.328 & 3.041 \\
\hline $\begin{array}{l}\text { Ln( } \text { Inco }_{i, t} / I^{\prime} \text { Ino }_{i, t-} \\
\text { ) }\end{array}$ & 8610 & 0.087 & 0.628 & -2.145 & 2.409 \\
\hline D & 8610 & 0.356 & 0.479 & 0 & 1 \\
\hline Fee & 8610 & 0.187 & 0.118 & 0.026 & 0.645 \\
\hline Size & 8610 & 22.215 & 1.262 & 19.953 & 26.019 \\
\hline Lev & 8610 & 0.401 & 0.193 & 0.048 & 0.846 \\
\hline Roa & 8610 & 0.074 & 0.048 & 0.003 & 0.256 \\
\hline PPE & 8610 & 0.211 & 0.140 & 0.005 & 0.642 \\
\hline INVE & 8610 & 0.140 & 0.104 & 0 & 0.524 \\
\hline GDP & 8610 & 7.399 & 0.872 & 6.600 & 10.600 \\
\hline
\end{tabular}

\begin{tabular}{|l|l|l|l|l|l|}
\hline Private & 8610 & 0.339 & 0.473 & 0 & 1 \\
\hline Cash & 8610 & 0.057 & 0.046 & -0.028 & 0.221 \\
\hline SRZC & 8610 & 0.679 & 0.184 & 0.250 & 0.926 \\
\hline ENF & 8610 & 1.024 & 0.193 & 0.657 & 1.612 \\
\hline DA & 8610 & 0.059 & 0.145 & -0.736 & 0.567 \\
\hline Age & 8610 & 15.142 & 5.647 & 2 & 38 \\
\hline
\end{tabular}

\begin{tabular}{|c|c|c|}
\hline Variables & \multicolumn{2}{|c|}{$\mathbf{L n}\left(\mathbf{I} \mathbf{T}_{\mathrm{i}, \mathrm{f}} / \mathbf{I} \mathbf{T}_{\mathrm{i}, \mathrm{t}-1}\right)$} \\
\hline $\operatorname{Ln}\left(\operatorname{Inco}_{\mathrm{i}, \mathrm{t}} / \operatorname{Inco}_{\mathrm{i}, \mathrm{t}-1}\right)$ & $\begin{array}{r}0.726 * * * \\
(43.14)\end{array}$ & $0.712 * * *(41.25)$ \\
\hline $\begin{array}{l}\mathrm{D} \times \operatorname{Ln}\left(\operatorname{Inco}_{\mathrm{i}, /} / \operatorname{Inco}_{\mathrm{i}, \mathrm{t}}\right. \\
\text { 1) }\end{array}$ & $\begin{array}{l}-0.202 * * * \quad(- \\
7.87)\end{array}$ & $-0.215 * * *(-8.17)$ \\
\hline Constant & $0.274 * * *(3.52)$ & $0.372(1.49)$ \\
\hline Othercontrols & No & Yes \\
\hline Ind/Year/Dist & No & Yes \\
\hline R-squared & 0.301 & 0.303 \\
\hline $\mathrm{N}$ & 8610 & 8610 \\
\hline
\end{tabular}

Note: All continuous variables are winsorized at the $1^{\text {st }}$ and $99^{\text {th }}$ percentiles.

Table2. Regression RESULS OF MODEL(2)

Note:***, $* *, *$ denote statistical significance at $1 \%, 5 \%$ and $10 \%$, respectively.

\begin{tabular}{|c|c|c|c|}
\hline \multicolumn{2}{|c|}{ Model (1) } & \multicolumn{2}{|c|}{ Model (3) } \\
\hline Variable & InIT & Variable & $\begin{array}{c}\mathbf{L n}\left(\mathbf{I T}_{\mathrm{i}, \mathrm{f}} / \mathbf{I} \mathbf{I T}_{\mathrm{i}, \mathrm{t}-}\right. \\
\mathbf{1})\end{array}$ \\
\hline $\operatorname{Ln}\left(\operatorname{Inco}_{i, t}\right)$ & $\begin{array}{r}0.601 * * * \\
(33.53)\end{array}$ & $\operatorname{Ln}\left(\operatorname{Inco}_{\mathrm{i}, \mathrm{t}} / \operatorname{Inco}_{\mathrm{i}, \mathrm{t}-1}\right)$ & $\begin{array}{l}0.706 \\
(41.08) \\
* * *\end{array}$ \\
\hline $\begin{array}{l}\operatorname{Ln}\left(\operatorname{Inco}_{i, t}\right) x \\
\text { Fee }\end{array}$ & $\begin{array}{c}-0.102 * * * \\
(-2.21)\end{array}$ & $\begin{array}{l}\mathrm{D} \times \operatorname{Ln}\left(\operatorname{Inco}_{\mathrm{i}, \mathrm{t}} / \operatorname{Inco}_{\mathrm{i}, \mathrm{t}-}\right. \\
1)\end{array}$ & $\begin{array}{l}-0.793 \quad(\quad- \\
1.75) *\end{array}$ \\
\hline Fee & $\begin{array}{c}2.030 * * * \\
(2.31)\end{array}$ & $\begin{array}{l}\mathrm{D} \times \operatorname{Ln}\left(\operatorname{Inco}_{\mathrm{i}, \mathrm{t}} / \mathrm{Inco}_{\mathrm{i}, \mathrm{t}}\right. \\
1) \times \mathrm{Fee}\end{array}$ & $\begin{array}{l}-0.668(- \\
4.83) * * *\end{array}$ \\
\hline Constant & $\begin{array}{r}-4.389 * * * \\
(-13.23)\end{array}$ & Constant & $\begin{array}{l}0.325(4.14) \\
* * *\end{array}$ \\
\hline Othercontrols & Yes & Othercontrols & Yes \\
\hline Ind & Yes & Ind & Yes \\
\hline Year & Yes & Year & Yes \\
\hline Dist & Yes & Dist & Yes \\
\hline R-squared & 0.815 & R-squared & 0.309 \\
\hline $\mathrm{N}$ & 8610 & $\mathrm{~N}$ & 8610 \\
\hline
\end{tabular}
All continuous variables are winsorized at the 1st and 99th percentiles.

Table3. Regression RESULS OF MODEL(1)\&(3)

Note:***,**,* denote statistical significance at $1 \%, 5 \%$ and $10 \%$, respectively. All continuous variables are winsorized at the 1 st and 99 th percentiles.

Table 2 presents the regression results of model (2). It can be seen that the coefficients of the cross variable $D \times \operatorname{Ln}\left(\right.$ Inco $_{i, t} /$ Inco $\left._{i, t-1}\right)$ are -0.202 and -0.215 , both of which are significant at the level of $1 \%$, indicating the existence of tax stickiness in China's listed companies. Through the analysis of the regression coefficient, for every one percentage point increase in total accounting profits, the corporate tax burden rises by 0.726 or 0.712 percentage points, while for every one percentage point decrease in total accounting profits, the corporate tax burden drops only by 0.524 or 0.497 percentage points.

The regression results of model (1) are shown in the left half of Table 3. It can be seen that the coefficient of $\operatorname{Ln}\left(\operatorname{Inco}_{i, t}\right)$ is 0.601 , which is significantly positive at the level of $1 \%$. It shows that there is a highly positive correlation between the enterprise income tax burden and the total profit. Every $1 \%$ change in the total profit, the enterprise income tax burden changes by $0.601 \%$. The coefficient of $\operatorname{Ln}\left(\right.$ Inco $\left._{i, t}\right) \times \mathrm{Fee}$ is -0.102 , which is significantly negative at the level of $1 \%$, which means 
transaction costs can reduce the sensitivity of tax burden to profit change.

The right half of Table 3 shows the regression results of model (3). The regression results show that the coefficients of cross variable $D \times \operatorname{Ln}\left(\right.$ Inco $_{i, t} /$ Inco $\left._{i, t-1}\right)$ and $D \times L n\left(\right.$ Inco $_{i, t} /$ Inco $\left._{i, t-1}\right) \quad \times F e e$ are -0.793 and -0.668 respectively, and they are significantly negative at the level of $5 \%$ and $1 \%$, respectively, which indicates that the stickiness of corporate income tax increases with the increase of transaction costs.

\section{Conclusion}

According to the Chinese tax law, the transaction costs exceeding the standard cannot be deducted before tax. If the transaction cost rate is too high, the tax burden of enterprises will not normally decrease with the decrease of accounting profit, which will increase the stickiness of enterprise tax burden. Based on the big data samples of Chinese listed companies from 2009 to 2018, this paper empirically tests the relationship between transaction costs and corporate tax stickiness. The empirical results show that with the increase of transaction cost rate, the stickiness of corporate tax burden will be strengthened. The results show that the rise of transaction costs, and the decline of profits of more enterprises in the economic downturn are the important reasons for the heavier tax burden of enterprises in the period of economic downturn..

\section{References}

1. B. Q. Wang, C. L. Sun, L. N. Wu, and G. H. Jiang, "Research on the stickiness of enterprise tax payment: Based on the perspective of government tax collection and management" J. Accounting research, vol. 5,pp. 28-35, May 2018 [in Chinese].

2. J. Liu, W. Xue, F .Liu, "Tax rigidity: the tax burden characteristics of Chinese enterprises under the planned tax collection and management mode" J. Contemporary accounting review, vol. 12,pp. 122,May 2019 [in Chinese].

3. Y. X. Bai, W. Z. Tang, G.Liu, "Tax planning and corporate tax burden" J. Economic research, vol. 54,pp. 98-112,May 2019 [in Chinese].

4. Z. Q. Li, W. B. Lu, "Conservatism of Accounting Earnings: discovery and Enlightenment" J. Accounting research, vol.2,pp. 19-27,2003 [in Chinese].

5. L.Liu, "On the taxation principle of enterprise income tax” J. Tax researc, vol. 4,pp. 31-35,April,2006 [in Chinese].

6. H. S. Hu, Q. Wu, "The causes of the stickiness of corporate income tax and its impact on the upgrading of local industrial structure" J. Financial research, vol.7,pp. 113-129, July 2020 [in Chinese].

7. X. Liu, K. T. Ye, "Financial development, property rights and corporate tax burden" J. Management world, vol.3,pp. 41-52, 2014. [in Chinese]
8. Y. C. Feng, "Research on the relationship between political connection and tax burden of Chinese private enterprises" J. Management review, vol. 24,pp. $167-$ 176,June 2012 [in Chinese].

9. H. Luo, Y. L. Zeng, B. H. Liu, "Executive compensation, corporate governance and Cost Stickiness in state owned enterprises" J. Economic Journal, vol. 32,pp. 99-104,Febury 2015 [in Chinese].

10. R. D. Banker, "Employment protection legislation, adjustment costs and cross-country differences in cost behavior" J. Journal of accounting \& economics,vol.55, August 2013. 